\title{
The potential of labour management partnership: a longitudinal case analysis
}

\section{Stewart Johnstone and Adrian Wilkinson}

\section{British Journal of Management}

\begin{abstract}
Issues of labour management cooperation have long attracted the attention of management researchers, practitioners and policymakers. In Britain, the most recent wave of interest has been under the rubric of labour management partnership, normally concerning the development of cooperative relations between unions and employers. A recurring theme is that cooperative relations can be difficult to develop and sustain, especially in liberal market economies. This article advances the debate by examining the dynamics of labour management partnership within the context of a British financial services organisation over a twenty-five-year period. Drawing upon empirical case study data collected between 1990 and 2014, the article assesses the dynamics of the relationship between a building society and the recognised staff union. We confirm the possibility of sustaining collaborative relationships associated with a mutual gains agenda within a liberal market economy as well as the fragility of such arrangements. While we acknowledge that sustaining cooperative regimes can be difficult, we also caution against the tendency towards institutional determinism and underplaying of agency in many of the partnership critiques.
\end{abstract}




\section{Introduction}

Issues of labour management cooperation have long attracted the interest of management researchers, policymakers and practitioners. In Britain, the most recent wave of interest has been under the rubric of labour management partnership (LMP) which gained momentum in the UK in the 1990s. Though partnership was an imprecise term (Bacon and Storey, 2000; Guest and Peccei, 2001), for most industrial relations (IR) specialists, partnership was a pluralist project concerned with promoting cooperative relations between unions and employers (Oxenbridge and Brown, 2004). Ackers and Payne (1998) and Kelly (1996) set out the normative case for and against cooperative union management partnerships, and numerous empirical studies have since examined the benefits and risks for employers, unions and their members in the UK (Brewster et.al, 2014; Butler et.al, 2011; Danford et.al, 2005; 2008, 2014; Johnstone et.al, 2010; Johnstone et.al, 2011; Kelly, 2004), Ireland (Dobbins

and Dundon, 2016; Geary and Trif, 2011) and the United States (Kochan, 2016). The findings are far from clear cut; it is possible to find evidence to support the mutual gains arguments of the advocates, the risks and challenges identified by the critics, and all the various points in between (Johnstone et.al, 2009; Johnstone, 2014).

Three main camps can be observed, and reflect the 'frames of reference' which inform the main research traditions in British IR (Fox, 1966, 1974; Edwards, 2017; Kaufman 2014; Heery, 2015, 2016). First, the most ardent empirical critiques, written from within the radical and labour process traditions and influenced by political Marxism, argue that the fundamental dynamics of capitalism render union management cooperation for mutual gain flawed and contradictory, and reject collaborative partnership approaches in favour of more militant unionism (Danford et.al, 2005, 2008, 2015; Danford and Richardson, 2016; Kelly, 1996; Upchurch et.al, 2008). Second, are radical pluralists, who combine elements of radical and pluralist thinking, stressing how capitalism creates a 
‘structured antagonism’ between workers and management (Edwards, 1986; see also Dundon and Dobbins, 2015). Writers in this tradition also offer a critique of capitalist social relations but distance themselves from Marxist political projects. Though not opposed to partnership per se, they are pessimistic regarding the potential of diffusing and sustaining LMPs in liberal market economies (LMEs), due to the systemic pressures of neoliberal capitalism, limited statutory regulation and dominance of MNCs (Dobbins and Dundon, 2016b; Simms, 2015). Without reforming the institutional environment, LMP is believed to be a chimera in voluntarist institutional contexts (Dobbins and Dundon, 2016). In the final camp reside neo-pluralist commentators who express concerns regarding the risks of becoming trapped in an "iron cage" of institutional determinism which underplays the role of actor action in shaping institutions (Ackers, 2002; Ackers, 2014). Heery (2015) also observes how "there is a trend in pluralist work to downplay the agency of employers viewing them instead as 'institution takers' confirming to systemic imperatives that operate above the level of the firm [rather than] actors with the potential for significant agentic action” (p.31) Neo-pluralist commentators are more optimistic regarding the potential of localised actor agency, including the role of management and union champions, in sustaining collaborative partnerships within capitalist neoliberal market economies. They are also pessimistic about the future of unions in LMEs without partnership (Ackers, 2015; Donaghey, 2016; Johnstone, 2015; Johnstone and Wilkinson, 2016). As Heery (2016, 123) notes, "the dispute over partnership echoes many earlier clashes between the pluralist and critical frames, and is a manifestation of a fundamental line of cleavage, a zone of contention within the field". However, as the above discussion illustrates, this is no longer just a clash between the critical and pluralist frames but also an important point of contention within the pluralist frame; neo-pluralists view radical pluralists as having moved too close to the radical perspective while radical pluralists view neo-pluralists as shifting towards unitarism (Ackers, 2014; Dundon and Dobbins, 2015).

Yet despite contentious debates regarding the desirability of LMP, as well as a voluminous (but inconclusive) empirical literature assessing the outcomes, our knowledge of the dynamics at the enterprise level remains partial and incomplete (Butler et.al, 2011). Many studies offer a snapshot into 
the outcomes of specific incidents and initiatives (see for example Johnstone, 2010). However, radical, radical pluralist and neo-pluralist commentators all accept that instances of partnership are possible; where they differ is the desirability and sustainability of such arrangements. We thus need to understand how and why LMP evolves and survives in some contexts but not others, ideally based on analysis over an extended period of time (Butler et.al, 2011; Geary and Trif, 2011; Oxenbridge and Brown, 2004). While some authors have traced relationships over a decade or more (see for example Kochan, 2016) such studies are rare but vital if we are to understand why LMP survives or falters. This is the motivation for the present paper. Our empirical focus is the relationship between an employer (a British building society) and a trade union (an internal staff union) over a twenty-fiveyear period (1990-2014). Three main questions guided the study:

(1) Why did labour management cooperation develop at the enterprise level?

(2) How did labour management cooperation evolve over time?

(3) Which factors supported and hindered sustainable labour management cooperation?

Our paper makes several contributions. Empirically, we provide rare insights into labour management cooperation in the context of building societies, a sector renowned for cooperative union management relations but largely absent from the partnership debate of the 1990s (Gall, 2008). Secondly, our engagement with union and management actors over a twenty-five-year period allows us to provide much needed longitudinal insights into how cooperation ebbs and flows over time. Conceptually, we make a contribution to recent debates in this journal regarding the longevity of workplace partnership in liberal market economies (Dobbins and Dundon, 2016b) as well broader debates regarding the influence of context and institutions on strategy, HRM and employment relations (Lange et.al, 2015; Tregaskis et.al, 2013; Witcher and Chau, 2012; Wood and Budhwar, 2014).

\section{Theoretical perspectives on the dynamics of labour management cooperation}

The notion of frames of reference (Fox, 1966), has been influential in evaluating labour management strategies at the enterprise level (Heery, 2015; 2016). Early distinctions between unitarism and pluralism provided a way of explaining employer preferences for managing with or without trade 
unions (Fox, 1966). However, there has also been increasing recognition that there are different shades of unitarism and pluralism. Heery (2015) notes how a unitarist employer might seek to avoid any challenge to managerial prerogative and limit employee voice (hard unitarism) or support employee voice but without trade unions (soft unitarism). In IR, debates about labour management cooperation have usually been located within the pluralist frame and concerned with the role of trade unions. Classic IR pluralism generally had little to say on issues of cooperation, though the potential for a more cooperative pluralism was evident in Flanders (1964) study of the Fawley productivity agreements in the UK, and Walton and McKersie's (1965) influential distinction between integrative and distributive bargaining in the context of US industrial relations.

A recent contribution by Bray et.al (2015) is a welcome development in helping conceptualise the dynamics of labour management co-operation at the enterprise level (see Figure 1). First, they define cooperation as "managers, workers, and their representatives, if any, working together towards the same end", and note how "working together involves ongoing relationships that operate over a period of time rather than specific 'events' or 'transactions'” (p.4, our emphasis). Informed by frames of reference, the authors propose six main perspectives on cooperation in the employment relationship, and translate these into different workplace scenarios. At one end is the radical perspective where cooperation is fundamentally contradictory and at the other is the market/egoist perspective which views cooperation as automatic ${ }^{1}$. Between these two extremes are Unitarist and Pluralist perspectives. Unitarism rejects the need for third party intervention in the employment relationship, assumes a harmony of interests, and focuses upon decision making led by management. However, management decision making can be with limited consultation (Autocratic Unitarism) or more consultative (Consultative Unitarism). Pluralism, on the other hand, stresses the co-existence of common and divergent interests and values external representation and third party intervention. However, pluralism can also take different forms. Employment relations actors might seek to advance their

\footnotetext{
${ }^{1}$ In contrast to the usual three frames of reference (Edwards, 2017; Heery, 2015), Bray et.al (2015) follow Budd and Bhave (2008) and propose four frames of reference. For Budd and Bhave 'hard unitarism' is better viewed separately as an individualistic frame of reference in which rational agents pursue individual self interest in economic markets (Egoist). From this perspective unitarism is characterised by a unity of shared interest rather than self-interest.
} 
interests with little regard for those of others (Adversarial Pluralism) or work collaboratively to advance common interests (Collaborative Pluralism). For Bray et.al meaningful cooperation can only be achieved either as part of Consultative Unitarism or Collaborative Pluralism. Importantly, they note that sustaining cooperation is not easy and without effort and investment entropy can result.

\section{[FIGURE 1 ABOUT HERE]}

In contrast to much of the HRM and management literature, few IR scholars ascribe to a unitarist worldview. The main IR debate has therefore been concerned with the potential of developing and sustaining Collaborative Pluralism in national contexts - such as the English-speaking Anglo-Saxon nations - associated more with Adversarial Pluralism. Of course these are not 'pure' scenarios; conflict and cooperation are closely intertwined and it is conceivable that a conflictual issue could arise within a broadly cooperative relationship, or that there might be pockets of collaborative working within a generally adversarial relationship. Our study offers an ideal opportunity to test the utility of the 'cooperation curve’ framework (Bray et.al, 2015), by assessing patterns over time as well as the factors which promote or impede labour management cooperation. The remainder of the article is structured as follows. The next section presents the research context and outlines the research methods. We then present the findings and discuss the implications before drawing some conclusions.

\section{Research context}

\section{Building societies}

Our empirical focus is a large British building society 'BuSoc' (a pseudonym) and the relationship with its recognised staff association/staff union ${ }^{2}$. The British financial service industry has a long

\footnotetext{
${ }^{2}$ Known for many years as a Staff Association before changing its name to a Staff Union in 1997. Given the association has been an officially recognised union through the entire period of this study, and to avoid confusion we use the union nomenclature throughout this article.
} 
history of labour management cooperation between employers and representative bodies as well as high levels of union membership (Gall, 2008; Morris et.al, 2001, Wilkinson and Holden, 1991). However, building societies have always remained a distinctive segment of the British financial service industry (Snape et.al, 1993). Founded in the nineteenth century to provide loans for residential mortgages, they are generally small with strong local roots and limited international operations. They are also mutual organisations owned by members rather than shareholders, and at least $50 \%$ of funds must be raised in the form of shares held by members. As a result, societies are believed to adopt a low risk, long-term perspective to business rather than short-term profit maximisation. Until the 1980s the regulatory environment meant societies enjoyed a near monopoly over mortgage provision and considerable insulation from competition (Callen and Lomax, 1990). However, deregulation of the British financial service industry in the 1980s blurred the traditional boundaries between the activities of building societies and retail banks. Deregulation also allowed societies to 'demutualise' if support from members was forthcoming, and this was the path subsequently taken by many larger building societies attracted by the ability to raise capital and expand operations by issuing ordinary shares ${ }^{3}$. Interestingly, while many investor-owned banks and all demutualised building societies were high profile casualties of the 2008 financial crisis, building societies generally weathered the storm. The mutual business model, low risk appetite and limited involvement with 'subprime' lending or international wholesale credit markets may explain their resilience (Llewellyn, 2017), and there has been a resurgence of interest in mutual and employeeowned businesses since the financial crisis (Michie et.al, 2017; Salaman and Storey, 2016).

\section{Staff associations}

Employee representation in building societies is also distinctive. Most building societies created internal 'staff associations' in the 1970s. In-house staff associations were already common in the banking sector where they often coexisted and competed with the main banking union, the National Union of Bank Employees (Bain, 1970). Bank staff associations were renowned for espousing

\footnotetext{
${ }^{3}$ These include Abbey National in 1989, Cheltenham and Gloucester in 1995, Halifax and Northern Rock in 1997, and Bradford and Bingley in 2000.
} 
cooperation with employers and their opposition to the use of sanctions such as industrial action (Crompton, 1976; Robinson, 1967). While only one staff association existed in a building society in 1971 at least 25 had been created by 1984, as "presumably an informed employer realised some form of collective bargaining was likely and to resist the homegrown variety was to invite far more undesirable strangers into the organisation” (Swabe and Price, 1984, 199). Membership levels of two thirds of employees suggested some appetite for collective employee representation in the sector (Swabe and Price, 1984). In contrast to non-union company councils, building society staff associations were to be independent 'company unions' with collective bargaining rights, and funded by membership subscriptions. ${ }^{4}$ Yet unlike most trade unions, staff associations were internal bodies representing employees working for a single employer. Arbitration clauses also meant industrial action was technically possible but highly unlikely (Swabe and Price, 1984). Purcell (1984) suggested three possible scenarios for these new in-house staff associations/unions: they could fade away; act as a staging post to ‘mainstream’ unionism, or develop into bodies largely akin to mainstream unions. Many have indeed faded away, often as a consequence of organisational restructuring and mergers, and little is known about those that have survived.

\section{Methods}

In common with many studies of labour management partnership we adopt a qualitative case study design. However, in contrast to existing 'snapshot' studies, the research draws upon empirical insights obtained at five different points over a twenty-five-year period (1990-2014). This allows us to go beyond analysis of particular transactions and incidents (for example Johnstone et.al, 2010), and to explore relationship dynamics over time (Bacon and Blyton, 1999; Bray et.al, 2015). The employer and union have participated in a series of research projects conducted by the authors on the subject of employee participation, voice and representation, and the research is thus the product of numerous site visits, meetings and interviews since 1990. The first period, in the early 1990s was one year after the launch of the union in its current form. Twenty interviews were conducted in 1990 with staff at Head

\footnotetext{
${ }^{4}$ In the UK, the Certification Officer maintains a list of trade unions and can certify their 'independence'. Independence is currently defined as 'not under the domination or control of an employer' and 'not liable to interference by an employer'. Criteria include history, membership base, structure and finance.
} 
Office, Divisional and branch level, as well as union officials and representatives. Further in-depth interviews were then conducted with the General Secretary and Union President in 1997. The third tranche of fieldwork was during the period 2003-2007, and included eighteen interviews with senior management, union representatives, full-time union officials, HR specialists and front line employees. In-depth interviews with the General Secretary and Head of Employee Relations were then repeated in 2010 and 2014. The study thus draws upon insights obtained from forty-four interviews over a twenty-five-year period. In several cases the same respondent has been interviewed at various intervals. All interviews were recorded and transcribed.

Insights obtained during formal interviews were supplemented by further, and sometimes quite lengthy, discussions over lunch or coffee. These informal encounters allowed interpretations to be clarified and provided valuable additional insights. Given the focus of this article, we draw most heavily with our discussions with senior union and management figures, but the overall argument is informed by our engagement with a broad range of actors over more than two decades. Interviews were coded using categories which emerged from the interview schedules and research questions (Lofland and Lofland, 1995). Though the schedules used differed in each phase, all included questions regarding the union-management agreement, employee representation structures, and nature of management union-relations. New categories also emerged from the data, especially in relation to particular incidents identified by respondents. The analysis thus includes an exploration of both themes which guided the interview schedules, as well as issues which emerged from interviewees. Generous access has also been provided over the years by both management and union actors to relevant policy documents, magazines, newsletters and presentation slides, as well as invitations to union 'away days'. These have provided an important opportunity to clarify, contextualise and triangulate interview findings. We thus respond to repeated calls for longitudinal research designs that allow us to explore labour management cooperation over time, and to capture the changing context, experiences and perceptions (Butler et.al, 2011; Dietz, 2004; Geary and Trif, 2011; Johnstone et.al, 2009). As with much case study research, some of the findings may be deemed context specific; however creating statistically generalizable findings was not the motivation for the study (Stake, 
1995). Moreover, when compared with other studies of LMP, and especially studies located in the British financial service sector, a degree of ‘analytical generalisation’ may be possible (Yin, 2013).

\section{Findings}

\section{Collective Union Management Agreements}

BuSoc employs more than 15000 employees across a network of 600 branches and two administration centres, and the Staff Union has had sole collective bargaining rights within BuSoc since its inception in the 1970s. The union was officially recognised as an independent trade union in the early 1980s and is financed by member subscriptions. The current structure was created in 1990 and coincided with the appointment of the first full-time General Secretary and the relocation of the union from company headquarters to a small rented unit in a nearby town, both important signals of being less employer dependent. The number of union personnel has increased from two in 1990 to almost twenty in 2014, including support staff, Case Officers and Full Time Officers. Other key roles include President, normally a staff member seconded for a period of two years, and a network of lay representatives within the organisation. Membership is high at around $75 \%$ and has generally been stable.

The formal arrangement between the employer and the union is officially set out in the Recognition and Procedure agreement. A noteworthy feature of this document is the formal list of items for negotiation, where the employer commits to negotiate with the union. This is important because the dispute resolution procedure commits both parties to enter binding arbitration if negotiations are unsuccessful. The arbitration clause also means that while possible industrial action is unlikely. One benefit of this agreement is that both parties are generally keen to avoid the zero sum nature of external arbitration, and the arbitration clause was believed to "focus the mind upon reasonable and sensible negotiations”. On the other hand, it also meant that on other issues the employer commits only to consult rather than negotiate, meaning unless proposals were unlawful the union "could fight 
but we could not go to arbitration to stop it” (Union President). Some union actors questioned the need for such a distinction, especially as uncontroversial issues such as mileage allowances were matters for formal negotiation, while contentious issues such as bonus payments were not. The General Secretary suggested that "perhaps we should take it as a backhanded compliment that the society want to keep to this list at is shows they know we will take them on and that we will do what we need to do to look out for our members”.

Phase 1 (1990-2007): Building Collaborative Relationships

In the first phase of research, the General Secretary made it clear that in his view building collaborative working relationships with business leaders was essential if the union was to be effective. Establishing positive relationships with managers and key decision makers was thus a priority, "making it easier getting to yes, and harder for them to just say no". The Union President echoed this view in 1997, and explained how "when I came into this job I was told the role is all about building trust and relationships with management”. The key relationship was between the General Secretary and the Chief Executive, with many discussions taking place "on the golf course or over a curry”. The Employee Relations Manager noted how "in many ways the General Secretary is the union... God forbid but if he got run over by a bus tomorrow, what would happen?” The Chief Executive was also said to be committed to maintaining good employment relations, and the mutual business model was believed to allow a more long-term view without the pressure to deliver to shareholders as is the case in investor-owned businesses. This did not mean the union would always agree with management; there was a recognition that sometimes interests will diverge and that the union has a duty to defend and protect member interests. The close working relationships forged between Personnel Consultants and union Case Officers were a good example of this, with both parties noting how they normally worked together to resolve discipline and grievance cases. A union Case Officer explained how "we try and step back from situations...to see the employer and employee perspective and to form an opinion. But we are separate, we retain our independence and are quite prepared to take the business on”. 
Overall, employer union relationships during this period were described as cooperative and respectful, and there were numerous examples of consultation and joint working to design new policies in areas such as performance management, flexible working and work-life balance. This did not mean that relations were always harmonious; pay negotiations were said to be a good example where relations were less convivial, though agreements were normally reached without arbitration and within a separate collective bargaining space. The emphasis on building cooperative relationships with the employer was not thought to jeopardise the independence of the union, although it was acknowledged that managing member perceptions was important. As the General Secretary explained "I think we've always been independent, although we collaborate in a 'partnership' or whatever you want to call it. Those who are aware of what goes on know that we are very independent. But if you asked someone in a branch in Oban they might think we are just another department of BuSoc”.

An important illustration of the concerns regarding demonstrating independence was the decision to rebrand as a 'staff union' in the late 1990s. Until this point, union leaders had preferred the term 'association', suggesting that it sounded less adversarial and had wider appeal "to our broad church of employees ranging from those in leafy Surrey to those in the Welsh Valleys”. High membership levels were thought to confirm that 'association' had sufficiently broad appeal but there was always a concern "that an association would never be viewed as a 'real union', the relationship would be viewed as too cosy, an add-on to management, we do what they say” (Union President). A decision was taken to rebrand as a 'Staff Union' and to affiliate to the TUC, but there was a reluctance to affiliate to a political party. There was also a reluctance to embrace the formal language of partnership which was fashionable at the time as it was associated with the cosy image the union was trying to avoid. By 2006, the assessment of employer union relationships at BuSoc were still broadly positive and union management cooperation was described by both parties as the default mode of engagement. Various factors supported the development of collaborative relations over the period. These included the commitment of key union and management figures to working together, early consultation, the mutual governance model and the paternalistic ethos of building societies. The formal recognition agreement also separated integrative and distributive issues, while the arbitration 
clause encouraged compromise with regard to the latter. Finally, the recession of the early 1990s had receded and for most of this period the economic climate had been buoyant. Yet as the Union President stated presciently in 2006:

"You do worry that there have been no really significant disagreements between us for years. To what extent is cooperation genuine? Would it evaporate if we said actually you can't do that on something really significant to the business? Or if we just dug our heels in on something and they thought we were being obdurate. To what extent is the good relationship dependent on things running pretty smoothly? How much is a genuine commitment to make things work even when we disagree?”

\section{Phase 2 (2007-2011): Relationship Under Pressure}

In 2007, a new Chief Executive was appointed and delegated union-management relations to another senior executive. While this meant the union still had access to a senior decision maker, the end of the direct union link with the CEO was interpreted as a sign of a shift in attitude. More important, perhaps, was the appointment of a new HR Director. Prior to 2007 relationships between union officers and HR staff were said to be close; informal chats and off the record conversations as well as invites to meetings or to comment on policy drafts were all believed to lubricate day to day relations and allow issues to be "nipped in the bud". Following the change in HR leadership union actors reported a gradual "distancing" of the union and an end to informal early consultation. There were also important structural changes as the business aimed to implement a HR Business Partner model, "to release Personnel Consultants from operational tasks and allow them to devote more time to supporting business strategy”. However, the close working relationships between Personnel Consultants, line managers and union officials were believed to have fractured as a result. Union Officials observed a general change in mood:

"Whereas in the past Personnel Consultants would tell the business not to be so bloody stupid or you'll end up at a tribunal, now they are just serving instructions from above. No one is interested any more until the instructions from our solicitors land on their desk. In the past we'd go out and play pool and darts with the HR folk. Well that certainly doesn’t happen anymore!” (Union Official). 
"I was at a meeting last week when the HR Manager banged on the table and said 'my boss wants to know where we stand on this position because he’s up for the fight'. I thought, oh, we've never really taken this kind of approach but if you want a fight we'll give you one. We've always taken the approach of let's talk, we might not agree, we might even fall out, but we'll always talk. The heat in industrial relations has definitely turned up recently.... a new dogmatic approach of we're not going to get into bed with you anymore. It's very much indicative of the culture change at the top" (Union Official).

In late 2007 early signs of the global financial crisis began to emerge in the wider economy. As a building society BuSoc funds the majority of mortgage lending from members' savings and is less exposed to the vagaries of the global wholesale credit markets than banks. Societies are also known for a more cautious approach to lending, and BuSoc had not been directly involved with 'subprime' activity. Nevertheless, low interest rates are a challenge in a business that operates upon the margins between savings and mortgage rates, and in contrast to the buoyant economic conditions of Phase 1 , from 2008 the emphasis was upon reducing costs and improving productivity. The main union priorities were job security and protecting the enhanced redundancy terms offered by the employer. Following a nine-month consultation period, a union official explained how a number of redundancies were avoided where, "we worked together to identify alternative cost savings elsewhere which is essentially what they wanted to achieve”. The employer was also keen to introduce a new performance management system and discussions on this issue were more acrimonious. A key change was the shift away from team and corporate based incentives towards individual bonuses. Whereas in the past union and management actors had normally worked together to devise mutually acceptable HR policies, including performance management policies, union actors suggested that on this occasion they had deliberately been excluded. An official remarked an invitation to attend a briefing on the proposals was rescinded and explained how:

“They think we don’t know what's going on if we are not at these meetings, but our members tell us! We were portrayed as wanting the lowest possible sanctions for our members regardless of 
circumstance but we've always been clear our role is to ensure fair play. If someone's stolen money we're not going to demand they're retained. We felt very misrepresented”.

A challenge was that some members began to perceive that the union had been side-lined by the employer, and if this were the case, perhaps industrial action was the only option. However, it was also very clear that union officials viewed industrial action in any private sector organisation as "a nuclear option”, preferring instead to persuade management, criticise their actions, and defend employees at Employment Tribunals where necessary. By 2010, both union officials and management respondents agreed that relationships had reached "at an all-time low". The pressing challenge for the union was that members appeared increasingly frustrated by the seeming inability of the union to counter increasing managerial unilateralism, but stable membership levels of around 75\% of the workforce offered a solid basis to fight their corner.

\section{Phase 3 (2011-2014): Rebuilding Relationships}

In 2011, a new Head of Employment Relations was appointed and a priority was improving industrial relations. She explained how in times of crisis "the focus can very quickly become all about delivery rather than stakeholder management" with businesses making expedient rather than strategic decisions. Employment relations priorities were thought to be particularly vulnerable, "and you quickly become the employer you deserve to be rather than the employer you want to be”. Following four years of arms-length and at times adversarial employer union relations, the Head of Employment Relations suggested the relationship had reached a critical juncture in 2011. On the one hand the business could continue to keep the union at arms-length "which is not positive employment relations by any stretch of the imagination”. More pragmatically, there was an acknowledgement that by failing to working with the union, union officials might eventually feel there is no alternative but to accede to member demands for industrial action. Alternatively, the business could aim to return to relations before 2008 when the union was generally accepted as a legitimate and valuable partner in the development of HR policies and positive employment relations. The Head of Employment Relations suggested that senior leaders should value the union arrangement where "most of the officials are former employees who totally get the commercials, they understand the business, have an 
encyclopaedic knowledge of HR policy and procedure, don't breach confidentiality, and don’t speak to the press".

Interestingly, while during Phase 1 (1990-2007) the union had been opposed to the term 'partnership', by Phase 3 the language of partnership was increasingly commonplace in union and management literature. The Recognition and Procedure agreement was updated to include a short preamble regarding a joint commitment to "working together" and stressing the value of a "relationship between the union and BuSoc based on mutual respect, conducted in a spirit of openness, trust and integrity and acknowledges the legitimate interests of each party”. In addition, while in Phase 1 the emphasis was upon informal relationships at a very high level, especially those between the General Secretary and the Chief Executive, there was now greater emphasis on formalising and embedding consultation structures and processes throughout the business. Previously formal structures had existed primarily in the distributive collective bargaining space, while more integrative concerns were addressed through informal dialogue. Though collective negotiation and individual representation procedures had always been clearly specified in the recognition agreement, union actors acknowledged the fragility of consultation arrangements based upon goodwill and personal relationships.

Given this vulnerability, union officials were increasingly enthusiastic about re-energising and embedding an Employee Involvement Committee created in 2005 in response to the Information and Consultation Directive. The quarterly EIC is the "forum for the mutual exchange or high level strategic information” and comprises senior business Directors, Heads of HR, and full-time union officials. By 2014, a network of monthly Business Change Committees had also been created in each division which are believed to augment the EIC structure, acting "as the forum for the mutual exchange of information and where necessary consultation and negotiation”. The committees comprise a senior director (Chair), Heads of HR, union full-time officials and lay union representatives. Business managers are required to present any proposals for organisational change at these meetings. In contrast to the informal and often ad hoc consultation arrangements of the period 1990-2007, formalisation was central to attempts to reinvigorate collaborative working. As a senior 
official explained, “it’s all about committees now and might sound like terrible red tape and doesn’t mean we will get everything we want but it's a way of getting our feet firmly under the table, and getting processes cemented in the way things are managed day to day. It's a consultation chain that goes right down to customer representatives in branch and back up to area and regional managers, then right up to executive directors looking at the society as a whole”. In 2014, management and union actors agreed that the new Business Committees promoted joint working on issues at an early stage, and had helped clarify mutual expectations regarding information, consultation and negotiation.

There were various signs that in Phase 3 employer union relations were recovering. The employer had purchased adverts in several national newspapers to publically thank their "most valuable assets" and this was believed to signal a change in mood. The business also became an official Living Wage Employer after years of union pressure. Union officials were sanguine and suggested that the economic situation had improved, and that the new Head of Employment Relations had been instrumental in encouraging the business to rebuild more inclusive and cooperative relations with the union. Greater formalisation of representative processes was also said to help cement agreed consultation protocols on issues of business change and clarify mutual expectations. It was acknowledged by both management and union actors that sustaining cooperation would always be difficult, especially when at times interests and priorities appear to diverge, but working together in the spirit of mutual gains was still deemed a worthwhile aspiration with the potential to deliver gains for all parties.

\section{Discussion}

How and why did labour management cooperation develop?

It is often suggested that it can be difficult to establish cooperative employment relations regimes at the enterprise level in liberal market economies (Bray et.al, 2015; Dobbins and Dundon, 2016). Our first objective was thus to explore why cooperative regimes can develop in a generally unfavourable institutional context. Previous studies of LMP in the UK suggest that attempts to encourage cooperation have often followed a period of crisis or major organisational change (Oxenbridge and 
Brown, 2004). In British banking, a sector renowned for union management cooperation for much of the twentieth century, interest in formal LMP followed industrial disputes in the 1990s regarding the introduction of new HRM practices (Gall, 2008). In other cases, cooperation has been viewed as an evolution of mature union management relationships, especially where a union has strong legitimacy and the employer is keen to involve them in issues of business change (Oxenbridge and Brown, 2004). In British building societies, representative arrangements were deliberately designed to facilitate collective bargaining and individual employee representation within a broadly cooperative framework. The formal separation of consultation and negotiation activities were central to this (Purcell, 1984; Swabe and Price 1984). Compulsory arbitration was also designed to promote compromise in negotiations and avoid the use of sanctions against employers (Purcell, 1984). This is similar to the 'new style agreements' made between some unions and employers in the 1980s (Bassett, 1986; Johnstone, 2016).

Yet formal agreements may reveal little about the actual conduct of employment relations. At BuSoc actors noted how the formal Recognition and Procedure agreement was focused upon resolving conflict rather than working together. Distributive issues such as pay and conditions generally resided within the formal collective bargaining space and the arbitration clause acted as an incentive to both parties to reach a compromise. However, there was also extensive evidence of joint working around HR policies and practices, and this normally occurred on a much more informal relational basis. Factors which were believed to have facilitated the development of collaborative working in the 1990s included the attitudes of the Chief Executive and General Secretary, the mutual business model which encouraged a balanced and long-term approach to business, as well as the history of the organisation as a benevolent and responsible employer. The above factors led to the development of a 'collaborative pluralism' in the 1990s which acknowledged mixed goals but also promoted mutual gains (Bray et.al, 2015). In line with the arguments of neo-pluralists regarding actor agency (Ackers, 2014), both parties made pragmatic calculations regarding the best way to achieve their goals and concluded that trying to working together was the best approach.

How did labour management cooperation evolve over time? 
Our second objective was to explore how cooperative regimes evolve over time. Sometimes partnership has been portrayed as a shift from 'adversarialism to cooperation' (Gall, 2001) or 'negotiation to consultation' (Oxenbridge and Brown, 2004). In their notion of a 'cooperative curve' (see Figure 1) Bray et.al, (2015) offer a more nuanced view and suggest a more fluid relationship between collaborative and adversarial pluralism that ebbs and flows. Their definition of collaborative pluralism combines both integrative and distributive elements, while adversarial pluralism is focused upon distributive issues. Our interpretation of the dynamics at BuSoc are illustrated in Figure 2. Phase 1 (1990-2007) can generally be described as a period of Collaborative Pluralism and joint working around mutual gains. This is not to say that relations were harmonious or both sides always agreed on all issues; the important point is that it was collaborative and not adversarial relations which both parties use to describe the overall zeitgeist (Bacon and Blyton, 1999). Some strong forces of entropy were encountered in Phase 2 (2008-2011) including a more difficult macroeconomic environment, the departure of key management champions, the restructuring of the HR function, and a range of controversial change initiatives. This resulted in a period of low trust adversarialism though some pockets of cooperation managed to survive. This confirmed both the fragility of voluntarist collaborative regimes on the one hand (Bray et.al, 2015) as well as the resilience of collaborative working and importance of actor agency on the other. The phase is best described as a period of Adversarial Pluralism albeit with some isolated but enduring examples of Collaborative Pluralism. Phase 3 (2011-2014) then saw attempts by both parties to rebuild a more Collaborative Pluralism. The formalisation of commitments to the principles of partnership and development of a more robust internal consultation infrastructure were central to this attempt to recast more positive unionmanagement relations.

[FIGURE 2 ABOUT HERE]

Which factors enable or hinder labour management cooperation?

Perhaps the key controversy regarding labour management cooperation is that it is difficult to sustain (Bray et.al, 2015; Danford and Richardson, 2016; Dobbins and Dundon, 2016b; Simms, 2015). For Marxist IR radicals, this is due to the irreconcilable class conflict inherent within capitalism regimes 
(Danford and Richardson, 2016; Kelly, 1996). For radical pluralists, it is lightly regulated liberal market capitalism rather than capitalism per se which is problematic, and means that without hard regulation to act as 'beneficial constraints' (Streeck, 1997), voluntarist LMPs at the enterprise level are likely to falter (Dobbins and Dundon, 2016; Heery, 2015; Simms, 2015). Neo-pluralists, however, warn of the risks of institutional determinism and stress the role of actor agency (Ackers, 2014; Johnstone, 2015). A key question is the extent to which other factors can act as localised 'functional equivalents' (Roche and Geary, 2002). Studies have suggested a range of supportive contextual conditions including buoyant economic conditions; stable product markets; advanced technology; and a quality or innovation rather than cost-oriented competitive strategy (Belanger and Edwards, 2007; Dobbins and Gunnigle, 2009). Other factors include high skills levels, strong unions, management enthusiasm, employment security and complementary HR practices, and the separation of adversarial/distributive collective bargaining from integrative/consensual joint consultation activities (Butler et.al, 2011; Kochan and Osterman, 1994).

\section{[TABLE 1 ABOUT HERE]}

In the case of BuSoc several factors helped sustain labour management cooperation. These include the formal separation of bargaining and consultation, as well as a compulsory arbitration clause which encouraged compromise in negotiations. The mutual business model was also believed to allow a more balanced, long-term orientation to business decisions compared to investor-owned businesses, as illustrated by the resilience of the sector during the 2008 financial crisis. Building societies also have a long history of cooperative employment relations and paternalistic management practices. Senior management and union figures were also generally committed to a cooperative engagement, and high membership levels and an internal focus afforded the union legitimacy as the collective voice of BuSoc employees. As Swabe and Price (1984) note, given the choice it is likely that a building society would prefer to work with an in-house union rather than an external union, and therefore has an interest in making the relationship work. At an operational level, strong informal relations were also forged between HR officers, union representatives and union officials. The case also provides 
some insights into the factors which can hinder cooperation. These include poor economic conditions which trigger sudden policy changes, key management champions leaving the organisation, and the fracturing of operational relationships between HR and the union as part of the restructuring of the HR function. Our study thus demonstrates both the fragility of voluntary partnerships and the possibility of such efforts being derailed due to changes in the internal and external context, as well as a level of resilience and the ability to recover from a tough period as a result of active actor renegotiation. Both parties also recognised the precariousness of informal partnership working and there has been a shift towards formalising partnership commitments and more deeply embedding consultation structures.

\section{Conclusion}

Issues of labour management cooperation, and especially union management cooperation, have long divided researchers and policymakers (Heery, 2016). The notion of labour management partnership is the latest incarnation of such debates, and various commentators have offered powerful conceptual arguments for and against, as well as empirical investigation into the outcomes of such arrangements. Our aim in this article was to move beyond the dominant 'who wins/who loses' focus of earlier studies, and to shed much needed empirical light upon how and why cooperative relations develop and evolve, as well as the factors which can support and hinder cooperative working. In many ways our empirical case can be interpreted as a sustainable case of union management cooperation. For most of the period, relationships between the union and employer were described by actors as cooperative, the union was normally involved in HR policy development and decision making, and the employer acknowledged the benefits of working with the union and their legitimacy as the voice of BuSoc employees. This does not mean that employment relations were conflict free or that both parties always agreed. The point is that in addition to distributive issues such as pay, there was also clear evidence of regular consultation and joint working on more integrative issues. This is consistent with what Bray et.al (2015) term Collaborative Pluralism. 
Is the arrangement an example of a sustainable labour management partnership envisaged by neopluralists or the fragility of partnerships suggested by radical and radical pluralist commentators? Much depends on how we define success. Haynes and Allen propose that partnership "represents not so much a bipolar movement from adversarialism to cooperation, but a movement from cooperation within an adversarial context to constrained conflict within a cooperative framework” $(2001,181)$. Bray et.al (2015) take a similar position, suggesting that Collaborative Pluralism involves the coexistence of distributive and integrative bargaining rather than a wholesale shift from one to the other. In reality conflict and cooperation are closely intertwined, and there is a need to consider which dominates, as well as to distinguish between the dynamics of overall relationships compared to relationships regarding particular issues. As Hyman $(1987,30)$ pointed out, all managerial strategies are 'routes to partial failure' but what counts as partial success in the area of partnership? We would contend that on balance BuSoc can be viewed as a partially successful, generally sustainable and resilient example of LMP in a liberal market context. However, the case also confirms the precariousness of voluntary cooperation (as all parties recognise in our case) as well as the risk of parties too easily retreating from such arrangements at any time (Bray et.al, 2015; Dobbins and Dundon, 2016b). Our study also demonstrates the utility of the Bray et.al, (2015) framework in encouraging a more dynamic analysis of the dominant trends over time. As with all typologies, it simplifies reality, most notably the theoretical separation of pluralist (union) and unitarist (non-union) arrangements (Clegg, 1979). As our case illustrates, they represent tendencies rather than 'pure forms'; in reality actors may shift between different frames of reference at different times or depending upon the particular issue. Organisations may also pursue distinct approaches within a single organisation perhaps recognising trade unions in some company sites with non-union arrangements at other company plants (Dundon et.al, 2015). Nevertheless, we believe the Bray framework represents a useful heuristic device and certainly enhances more static analyses of ‘management style’ precisely because it emphasises this fluidity and complexity. 
Debates around the potential for labour management partnership continue to reflect a 'major line of cleavage' and 'zone of contention' within British industrial relations research (Heery 2016). We would question radical Marxist critiques which suggest that the fundamental dynamics of capitalism render union management cooperation flawed and contradictory (Danford and Richardson, 2016; Kelly, 1996; Upchurch et.al, 2008). We would also question the view of radical pluralists such as Dobbins and Dundon $(2016,12)$ that "mutual collaboration between management and labour in the new workplace now appears to be largely a chimera in a climate of systemic financialised capitalism”. Though the authors suggest that systemic, societal and dominance effects influence rather than determine labour management relations, the above appears to leave little scope for purposeful agentic action. Our case suggests that parties are not naïve; they are acutely aware of conflicting interests but also recognise common interests and carefully plot their way through the changing landscape. In a recent critique of radical pluralism, Ackers (2014) has questioned the emphasis of radical pluralists upon the notion of 'structured antagonism' (Edwards, 1986), and warns of the “risk of loading the employment relationship with an expectation that conflict is somehow normal and cooperation deviant - turning upside down most common sense experience of work” (Ackers, 2014, 2616). Conversely, radical pluralists charge neo-pluralists with advancing cooperation over conflict, neglecting deeper structural and societal issues of conflict and power, and misrepresenting their position on cooperation in the employment relationship (Dundon and Dobbins, 2015). The 'zones of contention’ are clear; neo-pluralists view radical pluralists as having shifted too far towards a radical perspective, while radical pluralists contend that neo-pluralists are shifting towards a unitary ideology (Ackers, 2014; Dundon and Dobbins, 2015).

To conclude, we caution against the tendency towards institutional determinism and underplaying of localised actor agency in radical and radical pluralist critiques of partnership. Organisations facing similar conditions and constraints can follow quite different paths, suggesting there is more scope for actor agency than critics acknowledge, in other words the potential for 'contextualised choice' (Bacon, 2008). Labour management partnerships are no panacea, and can certainly be fragile and difficult to sustain in liberal market economies. Greater state support and employment regulation 
would therefore be welcome to help diffuse, stabilise and embed such regimes. In the meantime, and given the lack of a credible alternative, labour management cooperation remains an important public policy goal and should not be dismissed as a chimera.

\section{REFERENCES}

Ackers, P. and J. Payne (1998). 'British trade unions and social partnership: rhetoric, reality and strategy’, International Journal of Human Resource Management, 9, pp.529-550.

Ackers, P. (2002). ‘Reframing employment relations: The case for neo Relations Journal, 33(1), pp.2-19.

Ackers, P. (2014). 'Rethinking the employment relationship: a neo-pluralist critique of British industrial relations orthodoxy', International Journal of Human Resource Management, 25, pp.26082625.

Ackers, P. (2015). 'Trade unions as professional associations’ in Johnstone, S. and P. Ackers (eds), Finding a Voice at Work: New Perspectives on Employment Relations, pp.95-126. Oxford: Oxford University Press.

Bacon, N. and Blyton, P. (1999). 'Cooperation and conflict in industrial relations: what are the implications for employees and trade unions', International Journal of Human Resource Management, 19, pp.638-654.

Bacon, N. (2008), 'Management strategy and industrial relations in Blyton, P. E. Heery, N. Bacon and J. Fiorito, The Sage Handbook of Industrial Relations, pp. 241-255. 
Bacon, N. and P. Samuel (2009). 'Partnership agreement adoption and survival in the British private and public sectors', Work, Employment \& Society, 23, pp.231-248.

Bacon, N. and J. Storey (2000). 'New employee relations strategies in Britain: towards individualism or partnership?’, British Journal of Industrial Relations, 38, pp. 407-427.

Basset, P. (1986) Strike Free: New Industrial Relations in Britain. London: Macmillan.

Bain, G.S. (1970). The Growth of White-Collar Unionism. Oxford: Clarendon Press.

Bélanger, J. and P. Edwards (2007). ‘The conditions promoting compromise in the workplace’, British Journal of Industrial Relations, 45, pp.713-734.

Bray, M., J. Budd and J. MacNeil (2015). 'The many meanings of cooperation in the employment relationship and their implications', $17^{\text {th }}$ ILERA World Congress, South Africa.

Brewster, C., M. Brookes, P. Johnson and G. Wood (2014). ‘Direct involvement, partnership and setting: a study in bounded diversity’, International Journal of Human Resource Management, 25, pp.795-809.

Budd, J.W. and D. Bhave (2008). 'Values, ideologies, and frames of reference in industrial relations’. In P. Blyton E. Heery N. Bacon and J. Fiorito (eds), The Sage Handbook of Industrial Relations, pp.92-112. London: Sage.

Butler, P., L. Glover and O. Tregaskis (2011). 'When the Going Gets Tough'...: Recession and the Resilience of Workplace Partnership’, British Journal of Industrial Relations, 49, pp. 666-687. 
Callen, T.S. and J.W. Lomax (1990). 'The development of the building societies sector in the 1980s', Bank of England Quarterly Bulletin, 30(4), pp.503-10.

Clegg, H. A. (1979). The Changing System of Industrial Relations in Great Britain. Oxford: Oxford University Press.

Crompton, R. (1976). 'Approaches to the study of white-collar unionism', Sociology, 10, pp.407-426.

Danford, A. and M. Richardson (2016). 'Why Partnership Cannot Work and Why Militant Alternatives Can: Historical and Contemporary Evidence'. In S. Johnstone and A. Wilkinson (eds), Developing positive employment relations: international experiences of labour management partnership, pp.49-76. Basingstoke, Palgrave.

Danford, A., M. Richardson, P. Stewart, S Tailby and M. Upchurch, (2005). 'Workplace partnership and employee voice in the UK: comparative case studies of union strategy and worker experience', Economic and Industrial Democracy, 26, pp.593-620.

Danford, A., M. Richardson, P. Stewart, S. Tailby and M. Upchurch (2008). 'Partnership, high performance work systems and quality of working life', New Technology, Work and Employment, 23, pp.151-166.

Danford, A., S. Durbin M. Richardson P. Stewart and S. Tailby (2014) 'Workplace partnership and professional workers: about as useful as a chocolate teapot?', International Journal of Human Resource Management, 25, pp.879-894.

Dietz, G. (2004). 'Partnership and the development of trust in British workplaces', Human Resource Management Journal, 14, pp.5-24.

Dobbins, A. and P. Gunnigle (2009). ‘Can voluntary workplace partnership deliver sustainable mutual gains?’, British Journal of Industrial Relations, 47, pp.546-570. 
Dobbins, T. and T. Dundon (2016). 'The chimera of sustainable labour-management partnership', British Journal of Management (Early View).

Dobbins, T. and T. Dundon (2016). 'Workplace partnership in Ireland: Irreconcilable Tensions Between an Irish Third Way of Voluntary Mutuality and Neoliberalism'. In S. Johnstone and A. Wilkinson (eds) Developing positive employment relations: international experiences of labour management partnership, pp.101-124. Basingstoke: Palgrave.

Donaghey, J. (2016). 'Trojan horse or tactic? The case for workplace partnership'. In Johnstone, S. and A. Wilkinson (eds) Developing positive employment relations: international experiences of labour management partnership, pp.49-76. Basingstoke: Palgrave.

Dundon, T. and T. Dobbins (2015). 'Militant partnership: a radical pluralist analysis of workforce dialectics’, Work, Employment and Society, 29(6), 912-931.

Edwards, P.K. (1986). Conflict at Work. Oxford: Blackwell.

Edwards, P.K., (2017). Making ‘Critical Performativity’Concrete: Sumantra Ghoshal and Linkages between the Mainstream and the Critical. British Journal of Management [online early].

Flanders, A. (1964). The Fawley Productivity Agreements. London: Faber \& Faber.

Fox, A. (1966). 'Industrial relations and industrial sociology’, Research Paper 3, Royal Commission on Trade Unions and Employers Associations, HMSO: London.

Fox, A. (1974). Beyond Contract: Work, Power and Trust Relations. London: Faber \& Faber.

Gall, G., (2001). 'From adversarialism to partnership? Trade unionism and industrial relations in the banking sector in the UK'. Employee Relations, 23(4), pp.353-375.

Gall, G. (2008). Labour Unionism in Financial Services. Basingstoke: Ashgate.

Geary, J. and A. Trif, A. (2011). 'Workplace partnership and the balance of advantage: a critical case analysis’, British Journal of Industrial Relations, 49, pp.44-69. 
Guest, D.E. and R. Peccei, R (2001). 'Partnership at work: mutuality and the balance of advantage’, British Journal of Industrial Relations, 39, pp.207-236.

Haynes, P. and M. Allen, (2001). 'Partnership as union strategy: a preliminary evaluation', Employee Relations, 23, pp.164-193.

Heery, E. (2015). ‘Frames of reference and worker participation’. In S. Johnstone and P. Ackers P (eds) Finding a Voice at Work: New Perspectives on Employment Relations, pp.21-43. Oxford: Oxford University Press.

Heery. E. (2016). Framing Work: Unitary, Pluralist and Critical Perspectives in the Twenty-first Century. Oxford: Oxford University Press.

Hyman, R. (1987) 'Strategy or structure? Capital, labour and control’. Work, Employment \& Society, 1, pp.25-55.

Johnstone, S., P. Ackers, and A. Wilkinson (2009). 'The British partnership phenomenon: a ten year review’, Human Resource Management Journal, 19, pp.260-279.

Johnstone, S. (2010) Labour Management Cooperation: Workplace Partnership in UK Financial Services. Basingstoke: Gower.

Johnstone, S., A. Wilkinson and P. Ackers (2010). 'Critical incidents of partnership: five years' experience at NatBank, Industrial Relations Journal, 41, pp.382-398.

Johnstone, S., A. Wilkinson, and P. Ackers (2011). ‘Applying Budd's model to partnership’, Economic and Industrial Democracy, 32, pp. 307-328.

Johnstone, S. (2014). 'Workplace Partnership’. In A. Wilkinson, J. Donaghey, T. Dundon, and R. Freeman, R (eds), The Handbook of Research on Employee Voice. Cheltenham: Edward Elgar Press. Johnstone, S. (2015). 'The case for workplace partnership’ in Johnstone. S. and P. Ackers Finding a Voice at Work: New Perspectives on Employment Relations. Oxford: Oxford University Press. 
Johnstone, S. (2016). 'Participation and Partnership in the UK: Progress and Prospects' in Johnstone, S. and A. Wilkinson (2016). Developing Positive Employment Relations, pp.77-99. Basingstoke: Palgrave.

Johnstone, S. and A. Wilkinson (2016). Developing Positive Employment Relations. Basingstoke: Palgrave.

Kaufman, B. (2014) An Employment Relations Model of Employee Voice.” In P. Ackers and S. Johnstone, eds. Finding a Voice? Employee Representation in the New Workplace. Oxford University Press, 278-99.

Kelly, J. (1996). ‘Union militancy and social partnership’. In P Ackers, C Smith and P Smith (Eds) The New Workplace and Trade Unionism, pp.79-109. London: Routledge.

Kelly, J. (2004). 'Social partnership agreements in Britain: labor cooperation and compliance', Industrial Relations: A Journal of Economy and Society, 43, pp.267-292.

Kochan, T. and P. Osterman (1994). The Mutual Gains Enterprise: Forging a Winning Partnership Among Labour, Management and Government. Boston: Harvard Business School Press.

Kochan, T. (2016). ‘The Kaiser Permanente Labour Management Partnership’. In Johnstone, S. and A. Wilkinson (eds) Developing positive employment relations: international experiences of labour management partnership, pp.249-280. Basingstoke, Palgrave.

Lange, K., M. Geppert, A. Saka-Helmhout, A. and F. Becker-Ritterspach (2015). 'Changing Business Models and Employee Representation in the Airline Industry: A Comparison of British Airways and Deutsche Lufthansa’, British Journal of Management, 26, pp. 388-407. 
Llewellyn, D. (2017) Conversion from Stakeholder Value to Shareholder Value Banks: The Case of UK Building Societies in Michie. J., C. Borzaga and J. Blaisi (2017). The Oxford Handbook of Mutual and Co-Owned Business. Oxford: Oxford University Press, pp.550-570.

Lofland, J and L.H. Lofland (1995). Analysing Social Settings: A Guide to Qualitative Observation and Analysis, Belmont CA.

Michie. J., C. Borzaga and J. Blaisi (2017). The Oxford Handbook of Mutual and Co-Owned Business. Oxford: Oxford University Press.

Morris, T., J. Storey, A. Wilkinson, and P. Cressey, (2001). 'Industry Change and Union Mergers in British Retail Finance’, British Journal of Industrial Relations, 39, pp. 237-256

Oxenbridge, S. and W. Brown, (2004). ‘Achieving a New Equilibrium? The Stability of Cooperative Employer-Union Relationships’, Industrial Relations Journal, 35, pp. 388-402.

Purcell, J. (1984). ‘Industrial relations in building societies’, Employee Relations, 6, pp.12-16. Robinson, O. (1969). 'Representation of the white-collar worker: the bank staff associations in Britain’, British Journal of Industrial Relations, 7, pp.19-41.

Roche, W.K. and J.F. Geary (2002). 'Advocates, critics and union involvement in workplace partnership: Irish airports’, British Journal of Industrial Relations, 40, pp.659-688.

Salaman, G. and J. Storey (2016). A Better Way of Doing Business? Lessons from the John Lewis Partnership. Oxford: Oxford University Press. 
Simms, M. (2015). 'Union organising as an alternative to partnership: or what to do when employers can’t keep their side of the bargain'. In S. Johnstone and P. Ackers (eds), Finding a Voice at Work: New Perspectives on Employment Relations, pp.127-152. Oxford: Oxford University Press.

Snape, E., T. Redman, and A. Wilkinson, (1993). 'Human Resource Management in Building Societies: Making the Transformation?', Human Resource Management Journal, 3, pp.43-60.

Stake, R. (1995) The Art of Case Study Research. Thousand Oaks, CA: Sage.

Streeck, W. (1997). 'Beneficial constraints: on the economic limits of rational voluntarism’. In J. Hollingsworth, J. Rogers and R Boyer (eds), Contemporary capitalism: The embeddedness of institutions, pp.197-219. Cambridge: Cambridge University Press.

Swabe, A.I.R. and P. Price, (1984). 'Building a permanent association? The development of staff associations in the building societies’, British Journal of Industrial Relations, 22, pp.195-204.

Tregaskis, O., K. Daniels, L. Glover, L. P. Butler, P. and M. Meyer (2013). ‘High Performance Work Practices and Firm Performance: A Longitudinal Case Study’, British Journal of Management, 24, pp. $225-244$

Upchurch, M., A. Danford, S. Tailby, and M. Richardson (2008). The Realities of Partnership at Work. Basingstoke: Palgrave Macmillan.

Walton, R.E. and R.B. McKersie, (1965). A Behavioral Theory of Labor Negotiations: An Analysis of a Social Interaction System. Ithaca: Cornell University Press.

Wilkinson A and L.Holden (1991) Long Term Patterns in Strategic Human Resources Management: A Case Study from financial services, International Journal of Employment Studies, Vol. 9, 
No. 2, pp. 1-26.

Witcher, B. J. and V.S. Chau, (2012). 'Varieties of Capitalism and Strategic Management: Managing Performance in Multinationals after the Global Financial Crisis’, British Journal of Management, 23, pp.58-73.

Wood, G. and P. Budhwar (2014). ‘Advancing theory and re- search and the British Journal of Management', British Journal of Management, 25, pp. 1-3.

Yin, R. (2013). Case Study Research: Design and Methods. Thousand Oaks CA: Sage. 
Figure 1: A Cooperation Curve Capturing the Challenging Dynamics of Cooperation in the Employment Relationship (Source: Bray et.al, 2015).

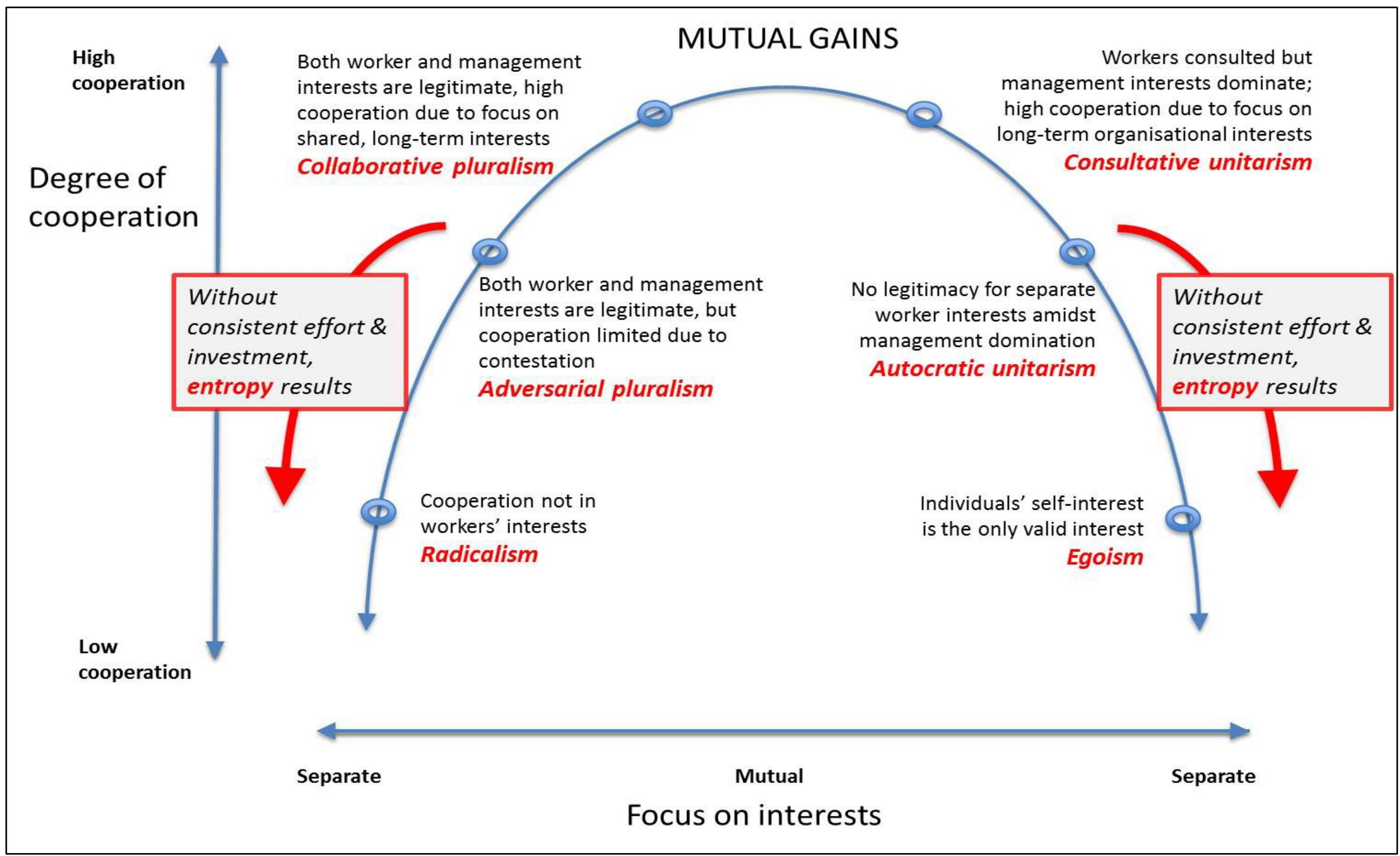




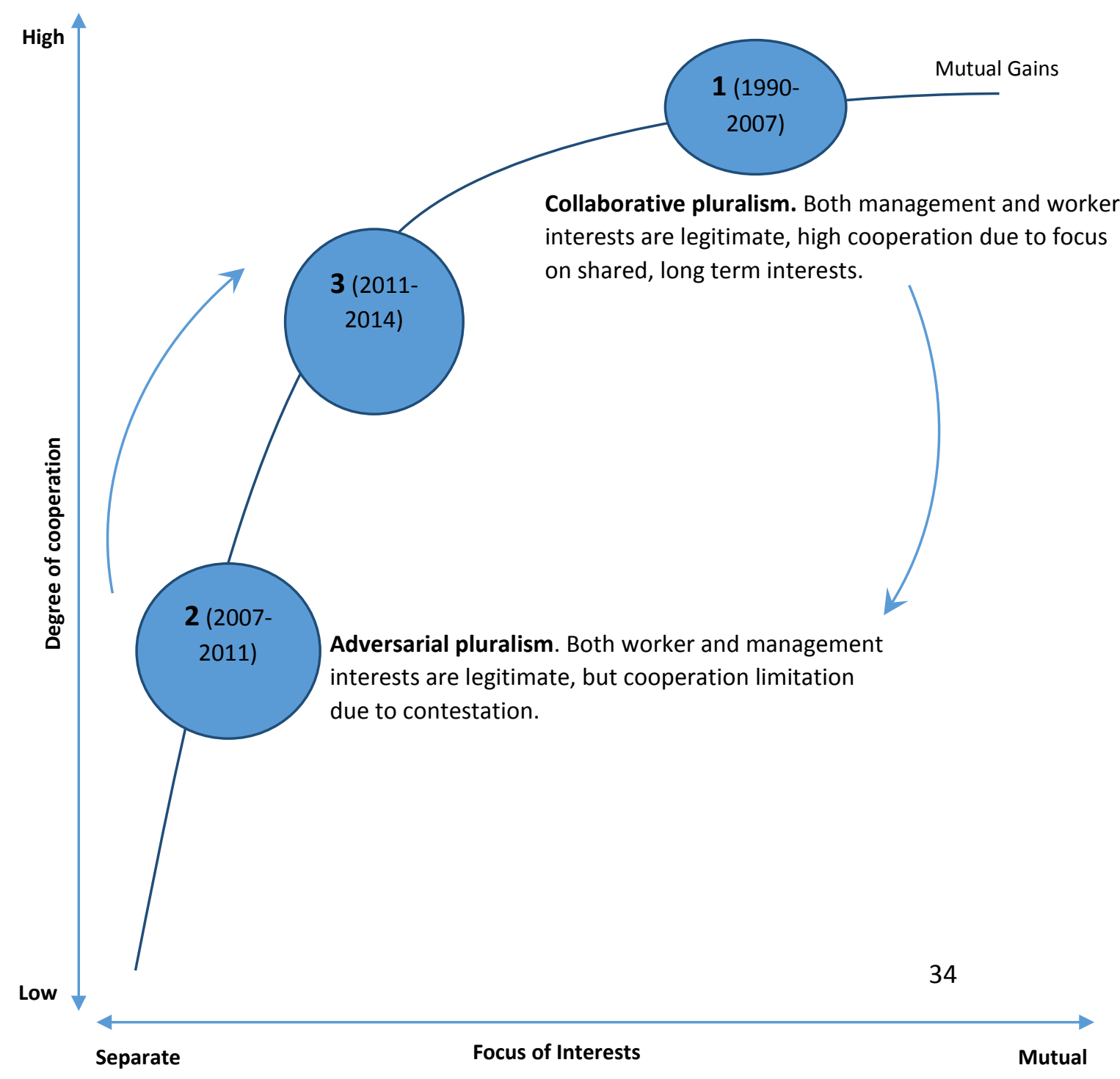


Table 1

Enablers and barriers to labour management cooperation

Phase 1 (1990-2007): Building Collaborative Relationships

External

$>$ Buoyant economic conditions

$\underline{\text { Internal }}$

$>$ Mature employer/union relationships

$>$ Internal union

$>$ Arbitration clause

$>$ Formal separation of collective bargaining and consultation

$>$ Union legitimacy (high membership, internal)

$>$ Support of senior union and management for cooperation and consultation

$>$ Strong informal relationships between union officials/senior managers

> Strong informal relationships between HR/union personnel

$>$ Long term view as mutual organisation

$>$ Supportive HR practices and traditions of the sector e.g. job security

Phase 2 (2007-2011): Relationships Under Pressure

External

$>$ Adverse economic conditions

Internal

$>$ New senior managers less support of cooperation and consultation with union

$>$ Organisational restructuring

$>$ Restructuring of the HR function

Phase 3 (2011-2014): Rebuilding Relationships

External

$>$ Improved economic conditions

Internal

$>$ Dissatisfaction with status quo

$>$ New senior managers supportive of cooperation and consultation with union

> Formalisation of consultation structures and commitments to cooperation for mutual gain 